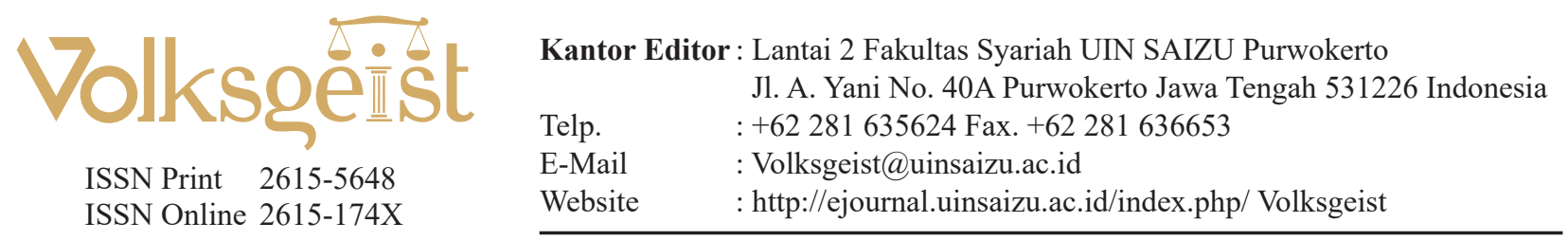

\title{
The Role and Function of Legal Aid Posts (Posbakum) at Biak's Religious Court Class IIB
}

\author{
Iryana Anwar, ${ }^{1}$ Muslim Lobubun \\ ${ }^{1}$ Sekolah Tinggi Ilmu Hukum Biak Papua \\ Email: iryanaanwar15@gmail.com
}

\begin{abstract}
This study aims to examine the roles and functions of the legal aid posts (Posbakum) at Biak Religious Court Class IIB according to the the national supreme court decree Number 1 of 2014. This study was carried out at Biak Religious Court by applying an empirical juridical approach. Data were collected through field observations and interviews with respondents. Data analysis was carried out in a qualitative descriptive manner. The results showed that the implementation of the legal aid units at Biak Religious Court in providing services for the poor in general had been carried out very well according to the national supreme court decree Number 1 of 2014, but the community still had difficulties for the unavailability of direct assistance by the units' officers. It is worried that those who receive legal services will fall into the category of people who are financially able to pay for an advocate. It was found that there are no regulations so far that stipulate the restriction (criteria) for people who are financially incapable of paying for advocate services. This research is expected to provide information for the people of Biak in particular, and people outside Biak in general regarding the benefits of legal aid services for the lower-class community.
\end{abstract}

Keywords: Religious courts, the legal aid posts (Posbakum)

\section{Abstrak}

Penelitian ini bertujuan untuk mengkaji peran dan fungsi pos bantuan hukum (Posbakum) pada Pengadilan Agama Biak Kelas IIB sesuai Keputusan Mahkamah Agung Republik Indonesia Nomor 1 Tahun 2014. Penelitian ini bertempat di Pengadilan Agama Biak Kelas II B. Penelitian menggunakan pendekatan yuridis empiris. Pengumpulan data dilakukan dengan observasi lapangan dan wawancara terhadap responden penelitian. Analisis data dilakukan secara deskriptif qualitative. Hasil Penelitian menunjukkan bahwa Implementasi penyelenggaraan Posbakum pada Pengadilan Agama Biak Kelas IIB dalam memberikan pelayan bagi masyarakat tidak mampu secara umum sudah dijalankan dengan sangat baik sesuai Keputusan Mahkamah Agung Republik Indonesia Nomor 1 Tahun 2014, namun masyarakat masih mendapatkan kesulitan karena belum tersedianya pendampingan langsung oleh petugas Posbakum, dikhawatirkan pihak yang memperoleh pelayanan hukum masuk kategori kalangan yang mampu secara finansial untuk membayar jasa advokat mengingat belum adanya peraturan yang menetapkan tentang batasan atau kriteria orang yang termasuk tidak mampu secara finansial dalam pembayaran jasa advokat. Penelitian ini diharapkan bisa menyediakan informasi bagi masyarakat Biak terutama, dan masyarakat di luar Biak secara umum terkait manfaat layanan Posbakum bagi masyarakat kelas bawah di Pengadilan Agama Biak Kelas IIB.

Kata Kunci: Pengadilan Agama, pos bantuan hukum (Posbakum) 


\section{Sejarah Artikel}

Dikirim: 30 Juli 2021

Direview: 04 November 2021

Diterima: 07 November 2021

Diterbitkan: 11 November 2021

\section{INTRODUCTION}

Poor people who do not understand legal procedures in submitting their cases to court sometimes find regulations and legal terms that are often considered procedural and even confusing. ${ }^{1}$ Both during the litigation process or non-litigation, all of which must be carried out based on the provisions of the law itself, or if not, the filing of the lawsuit will be rejected by the court due to not carrying out procedural steps.

Equality before the law must also be balanced with equal treatment (equal treatment), one form of equal treatment is realized by providing legal aid services to the poor, not only the rich able to get assistance from advocates but also the poor to get their rights (access to justice). ${ }^{2}$

Legal Aid Post strives to provide legal energy and ideas and legal works used to accommodate litigants. ${ }^{3}$ The existence of the Legal Aid Post intentionally protects the enforcement of the law. Based on this issue, the Supreme Court has issued Circular Number 10 of 2010 regulating the Basics of Providing Legal $\mathrm{Aid}^{4}$, especially in making application

1 Fauzan, "Penerapan Pemberian Bantuan Hukum Bagi Masyarakat Miskin Melalui Posbakum Di Pengadilan Agama Kota Bengkulu," MIZANI:Wacana Hukum, Ekonomi Dan Keagamaan 4, no. 2 (2017): 12534.

2 Ahyar, "Optimalisasi Pelayanan Bantuan Hukum Bagi Masyarakat Miskin," Jurnal Penelitian Hukum De Jure 20, no. 3 (2020): 409-34, https://doi. org/10.30641/dejure.2020.V20.409-434.

3 Agus Raharjo, Angkasa, and Rahadi Wasi Bintoro, "Akses Keadilan Bagi Rakyat Miskin (Dilema Dalam Pemberian Bantuan Hukum Oleh Advokat)," MIMBAR HUKUM 27, no. 3 (2015): 432-44.

4 Mahkamah Agung, "Surat Edaran Mahkamah letters or lawsuits for Prodeo cases, Jinayat cases, and circuit courts.

The Circular Letter of the Supreme Court concerning the basics of Providing Legal Aid does not work any longer. The Chief Justice of the Supreme Court has issued the Regulation of the Supreme Court of the Republic of Indonesia Number 1 of 2014 concerning the Basics of Providing Legal Aid for the Poor in Court on January 9, 2014. The direction has been in effect since its issuance, namely on January 16, 2014.

It contains the legal services for the poor, free court fees, conducting court proceedings outside the court, and establishing a court Legal Aid Post. ${ }^{5}$ It seems identical to the scope of legal aid services in court as stated in the previous Circular. In this study, the researcher focuses on the implementation of legal aid posts in the courts.

Legal Aid Post, is a place prepared at each Religious Court for legal aid service providers ${ }^{6}$ in providing legal assistance, namely legal consultation, legal advice, giving information, legal writing services, and giving information on the register of advocate institutions in accordance with Law Number 16 of $2011^{7}$ concerning Legal Aid institutions that can provide legal aid services for free. ${ }^{8}$

Guidelines on the issue of Legal Aid Posts in accordance with the provisions of the

Agung Nomor 10 Tahun 2010 Tentang Pedoman Pemberian Bantuan.” (2010).

5 Mohammad Kamil Ardiansyah, "Hukum Acara Perdata Di Lingkungan Peradilan Agama," Jurnal Ilmiah Kebijakan Hukum 14, no. 2 (2020): 361-84, https://doi. org/10.30641/kebijakan.2020.V14.361-384.

6 Isnandar Syahputra Nasution, "Urgensi Peran Pengadilan Dalam Memberikan Pelayanan Bantuan Hukum Terhadap Orang Miskin Sesuai Undang-Undang Nomor 16 Tahun 2011 Tentang Bantuan Hukum," Jurnal Hukum Dan Peradilan 4, no. 1 (2015): 171-88.

7 "Undang-Undang Nomor 16 Tahun 2011 Tentang Bantuan Hukum” (2011).

8 Angga and Ridwan Arifin, "Penerapan Bantuan Hukum Bagi Masyarakat Kurang Mampu Di Indonesia," Diversi Jurnal Hukum 4, no. 2 (2018): 218-36. 
Regulation of the Supreme Court is still found a number of problems, including the contribution of Legal Aid Posts to the extent of providing only information services, legal consultations, and making necessary legal documents, excluding any assistance directly in the proceedings.

Free cases are carried out in a particular way by Legal Aid Organizations, besides that the Legal Aid Post officers only provide information related to the Legal Aid Organization register. ${ }^{9}$ Of course, this is considered less effective and the defense should be free of charge through the Legal Aid Post without relying on the Legal Aid Organization that has been established by The National Department of Justice and Human Rights.

There are a number of previous studies that examine how the provisions of the Supreme Court regarding the role of legal aid posts in religious courts have been implemented.

First, research by Nyimas Lidya Putri Pertiwi and Firmansyah ${ }^{10}$, the Role of Legal Aid Post in Metro's Religious Court during the New Normal Condition, investigated how the Legal Aid Post continued to carry out its activities based on the regulations stated in the national Supreme Court Circular Number 2 of 2020 on Amendments to Number 1 of 2020 concerning Guidelines for the Implementation of Duties During the Prevention of the Spread of Covid-19 in the Supreme Court and Judicial Bodies. The research findings showed that the legal aid post had provided maximum service both online and offline by implementing health protocols for employees and justice seekers. Second, research by Rosita ${ }^{11}$, the Existence

9 Fransiska Novita Eleanora, "Bantuan Hukum Dan Perlindungan Hak Asasi Manusia Bagi Tersangka," Lex Jurnalica 9, no. 3 (2012): 142-50.

10 Nyimas Lidya Putri Pertiwi and Firmansyah, "Peran Posbakum Di Pengadilan Agama Metro Masa New Normal," Jurnal As-Salam 10, no. 1 (2021): 31-46, https://doi.org/10.51226/assalam.v10i1.213.

11 Rosita, "Eksistensi Pos Bantuan Hukum Dalam Memberikan Bantuan Hukum Di Pengadilan Agama of Legal Aid Posts in providing Legal Aid in the Watampone's Religious Courts class IB, investigated the existence of the Religious Court's legal aid post as crucial because of helping judges and clerks formulate lawsuits or requests. Third, the research by Yonna Beatrix Salamor about Providing Legal Aid to the Poor in Ambon City ${ }^{12}$, investigated the principle of quickly simple and low-cost justice, so that eliminated the view about high-cost legal aid service. In essence, the existence of legal aid for the poor is part of obtaining equal justice.

Of the three studies, researchers are interested in investigating the implementation of legal aid posts in Biak's religious court, therefore providing further information on whether or not the role of legal aid posts regulated in the provision works well.

The Biak's Religious Court has since 2020 provided free legal aid services to disadvantaged people in bringing lawsuits or applications, giving legal advice and consultations. The presence of this post is crucial in easing the task of the Court particularly for judges and clerks.

This study took place at Biak's Religious Court Class II B. The study used an empirical juridical approach. Data were collected through field observations and interviews with research respondents. Data analysis was carried out in a qualitative descriptive manner by classifying and sorting a number of data obtained, then related to the principles, theories, and legal rules of the data concerning the role of the Legal Aid Post (POSBAKUM). The data were then grouped and then a conclusion is drawn. ${ }^{13}$

Kelas I B Watampone," Jurnal Ekspose 16, no. 1 (2017): 250-60.

12 Yonna Beatrix Salamor, "Pemberian Bantuan Hukum Kepada Masyarakat Miskin Di Kota Ambon," Jurnal Muara: Ilmu Sosial, Humaniora \& Seni 2, no. 1 (2018): 277-83, https://doi.org/10.24912/jmishumsen. v2i1.1681.

13 Sulistyowati Irianto, "Metode Penelitian Kualitatif Dalam Metodologi Penelitian Ilmu Hukum," Jurnal Hukum \& Pembangunan 32, no. 2 (2020): 155 


\section{DISCUSSION}

\section{Benefits of Legal Aid Post}

A number of benefits can be obtained through the Legal Aid Post service. The public can obtain complete knowledge about the legal procedures that will be taken in court. ${ }^{14}$ They can also save costs during litigation, save time and energy through the Legal Aid Post service. ${ }^{15}$ There are a number of services provided by the Legal Aid Post in court. The services include: ${ }^{16}$

1. Provision of information and legal advice (legal advice).

2. The necessary legal paperwork services.

3. Providing information regarding the register of Legal Aid Institutions in accordance with the provisions of Law Number 16 of 2011 concerning Legal Aid Institutions or other Advocates who can provide free legal assistance.

The service of providing information in court means if justice seekers want to know about the stages of litigation in the Religious Courts, then the Legal Aid Post can provide an explicit explanation. Legal advice is the provision of legal advocacy by Legal Aid Post officers to service applicants. ${ }^{17}$ Another legal service is the provision of consultation, which provides legal consultation to each party in order to understand the essence of the case. Legal consulting services are carried out in accordance with the three basic

72, https://doi.org/10.21143/jhp.vol32.no2.1339.

14 Ahyar, "Optimalisasi Pelayanan Bantuan Hukum Bagi Masyarakat Miskin."

15 Ajie Ramdan, "Bantuan Hukum Sebagai Kewajiban Negara Untuk Memenuhi Hak Konstitusional Fakir Miskin," Jurnal Konstitusi 11, no. 2 (2014): 23355.

16 Perma, "Pasal 25 Peraturan Mahkamah Agung Republik Indonesia Nomor 1 Tahun 2014 Tentang Pedoman Pemberian Bantuan Hukum Bagi Masyarakat Yang Tidak Mampu Di Pengadilan.” (2014).

17 Supriyadi, Etika dan Tanggung Jawab Profesi Hukum di Indonesia, (Jakarta: Sinar Grafika, 2008), 55. ethics of counseling, namely confidentiality, volunteerism and independence. ${ }^{18}$

In making legal documents, what is needed includes making a lawsuit, as well as other documents related to legal procedures, either appeal, cassation, or review. ${ }^{19}$ The accommodation can be delivered by the Legal Aid Post officer because most people do not understand when it comes to formal legal terms. ${ }^{20}$ When the recipients hope to get defense from advocates or lawyers, the Legal Aid Post can only provide information about Legal Aid Organizations legally determined by the Ministry of Law and Human Rights in order to obtain free legal services. ${ }^{21}$

Hence, the Legal Aid Post cannot assist the litigants in court. This is very inefficient, given that the recipients cannot obtain a direct defense. It is only limited to services for making lawsuits or required legal documents. In addition, if the Legal Aid Post officer has given advice the applicant can use advocacy services for free, but if the applicant wants aid from a legal organization already verified and accredited for free legal service. In fact, the budget allocated for the legal services by the Ministry of Justice and Human Rights for these legal institutions have gone.

18 Hariyanto Hariyanto, "Peran LBH Kampus Di PTKIN Dalam Bantuan Hukum Terhadap Masyarakat Miskin," Al-'Adl 10, no. 1 (2017): 68-83, https://doi. org/10.31332/ALADL.V10I1.689.

19 Erie Hariyanto, Mohamad Efendi, and Sulistiyawati, "Dilema Hakim Pengadilan Agama Dalam Menyelesaikan Perkara Hukum Keluarga Melalui Mediasi," Volksgeist: Jurnal Ilmu Hukum \& Konstitusi 4, no. 1 (2021): 115-24, https://doi.org/10.24090/ volksgeist.v3i1.4333.

20 Gregorius Yolan Setiawan, Anak Agung Sagung Laksmi Dewi, and I Made Minggu Widyantara, "Efektivitas Bantuan Hukum Advokat Di Pos Bantuan Hukum (Posbakum) Pengadilan Negeri Denpasar Kelas I A," Jurnal Konstruksi Hukum 2, no. 2 (2021): 373-78, https://doi.org/10.22225/jkh.2.2.3258.373-378.

21 Ramdan, "Bantuan Hukum Sebagai Kewajiban Negara Untuk Memenuhi Hak Konstitusional Fakir Miskin." 
This made the Petitioners feel disappointed because they hoped to get assistance from advocates. If court Legal Aid Post officers can provide legal assistance as free of charge, then the applicant has no need to come to other legal institutions. This will make it easier for justice seekers and save time without finding institutions with extra budget able to provide free assistance. This is based on the function of the Legal Aid Post. The court's Legal Aid Post should also be able to simultaneously provide assistance to them in the court's litigation process. If there is a direct defense available by an advocate, the applicant will no longer have trouble finding and visiting a Legal Aid organization that can provide legal aid services for free. To get and visit a Legal Aid Organization also requires costs including transportation costs and it takes even longer.

\section{Legal Aid Services of Biak's Religious Court}

Biak's Religious Court in 2020 resolved 62 cases including 42 lawsuits (contentious) and 20 petition cases (volunteers). ${ }^{22}$ During January-March 2021, there are 15 cases handled by Biak's Religious Court; 9 lawsuits (contentious) and 5 petition cases (volunteer). ${ }^{23}$ The Legal Aid Post of Biak's Religious Court collaborated with the Legal Consultation and Aid Institute (LKBH) of Biak's School of Law in accordance with the cooperation agreement Number: W7-A1/437/HK.05/3/2017 February 12, 2020 and has also collaborated with the Office of Advocate Dr. Muslim Lobubun, S.H., M.H. \& Partners with the cooperation agreement Number: B.002/ML/II/20 February $16,2020 .{ }^{24}$ In 2020, a cooperation agreement was made by Biak's Religious Court with the 2020.

22 Biak's Religious Court, "2020 Annual Report,"

23 Biak's Religious Court, “January-May Case Report," 2020.

24 Biak's Religious Court, "Legal Aid Post Cooperation Agreement," 2020.
Legal Aid Service Provider Muslim Lobubun, S.H., M.H. \& Partners with the cooperation agreement number B.002/ML/II/20 February 16, 2020. Based on the MOU, a Work Contract Agreement Number W7-A1/437/HK.05/3/2020 February 12 2020, was issued. ${ }^{25}$

Considerations for the establishment of The Legal Aid Post Muslim \& Partners by Biak's Religious Court Class IIB in the 2020 fiscal year because the institution is a qualified and legal entity, and can work professionally. Based on these considerations, then the institution is recognized and worthy of providing legal aid services for the poor in seeking justice at Biak's Religious Court Class II B.

This is in line with the decision of the Supreme Court of the Republic of Indonesia Number 1 of 2014 Article 26 which confirms that the institutions that can implement the MoU with the Court are:

1. Civil society organizations providing legal advocacy, and/or

2. Working group of Legal advice at the Higher Education Legal Aid and Consultation Institute and/or Professional Advocates Organization.

In 2020, the budget provided for Legal Aid Post services at Biak's Religious Court amounted to Rp. 50.600.000,- (Fifty million six hundred thousand rupiahs) with a service target of 720 hours, but the Legal service was carried out more than the set target of 730 hours 6 minutes for 500 cases. The realization of the Legal Aid Post budget was 92.21 percent. ${ }^{26}$ For 2021 the budget provided is still Rp. 50,600,000, - (Fifty million six hundred thousand rupiah) with a service target of 740 hours. Until July 2021 , the realization of the total budget is 29.16 percent. ${ }^{27}$

25 Biak's Religious Court.

26 Biak's Religious Court, "Report on the Implementation of Legal Aid Post Services," 2020.

27 Biak's Religious Court, "Report on the Implementation of the Realization of Legal Aid Service 
There is a special place for Legal Aid Post services at Biak's Religious Court located in the courtroom, next to the space for registration of claims. This enables justice seekers to easily obtain Legal Aid Post services. In addition, the applicants can go to the Religious Court and meet the receptionist, and get directed to the information service officer.

This officer provides direction regarding the provision of legal services at Biak's Religious Court, legal aid services in accordance with the provisions of Article 25 of the Supreme Court Decree Number 1 of 2014. The applicant then goes to the officer by first completing the application form. The form is accompanied by the attachment of the original Certificate of Disability (SKTM), the original Certificate of Social Benefits, or a statement letter of being unable to pay for the advocate services. Furthermore, the applicant can obtain legal assistance services. ${ }^{28}$

The Secretary of the clerk and the Legal Aid Post Officer stated that all people can take advantage of the Legal Aid service not only people with middle to lower economic status but also people with the upper middle-class. ${ }^{29}$ According to the report on the 2020-2021 Legal Aid Post activities, there have been no applicants for legal aid services either asking for information, consulting, and legal advice as well as making the necessary legal documents attach a Certificate of Incapacity (SKTM) or a certificate of social benefits.

\section{Legal Aid for Underprivileged Communities}

It is the applicant with the prodeo case submission who only attaches these documents.

in July," 2020.

28 Legal Advice Officer, "Interview By Lobubun Muslim, Biak Religious Court Class IIB Biak On 12 May," 2021.

29 Deputy Clerks \& Legal Advice Officer, "Interview by Muslim Lobubun, Biak Religious Court Class IIB Biak On 12 May,” 2021.
It is problematic that the applicant's economic status can take advantage of the Legal Aid service which is intended for poor people. The requirements for unfortunate people according to Article 22 of the Supreme Court decree Number 1 of 2014, are those who are unable to finance the services of an advocate. In this Regulation, a person's income limit should have been determined based on the inability to finance the services of an advocate, the minimum monthly income, it is not only based on a statement of incapacity from the applicant and then approved by the Legal Aid Post officer.

Moreover, the party applying for legal aid is a State Civil Apparatus or Private Employee with a fixed income. If you wish to obtain information about the procedure for filing a lawsuit or the procedure in court, the applicant can obtain this information directly from the information officer at Biak's Religious Court. According to the results of interviews with the officers, the Legal Aid Post has carried out its functions through the provision of legal aid services including: $:^{30}$

\section{Provision of information}

Applicants for Legal Aid services who visit Biak's Religious Court generally want to seek justice, but unfortunately some do not know the procedures and requirements for registering cases and proceedings in the Religious Courts. This is caused due to several factors, namely low levels of education and lack of knowledge about legal procedures. The officers are just carrying out their duties as information providers. The officer first gave an explanation of the function and role of the Legal Aid Post. Then the officer asked what kind of legal aid service the applicant needed.

If the applicant only wants the provision of information, then the officer can explain the procedure for filing a lawsuit or application

30 Legal Advice Officer, "Interview By Lobubun Muslim, Biak’s Religious On 27 May,” 2021. 
as well as the procedures and requirements for the proceedings to be passed. The officers provide an understanding that the Legal Aid Post cannot work as a companion advocate, but can only provide assistance in terms of making the necessary documents such as lawsuit documents. In divorce cases, the Legal Aid officers also provide an understanding to the applicant as the first stage of mediation before seeking further action.

If the applicant wants a lawsuit, the officer will assist in making the lawsuit document. If the applicant belongs to a poor community who cannot afford to pay court fees, then the officer recommends that the applicant be able to propose a case on a free basis by completing the requirements.

\section{Legal Consultation}

The Petitioner may consult with the officer at the Court regarding his problems. If the problems are related to marriage, wills, inheritance, grants, and so on, the officer can provide solutions to these problems and also procedures need to be passed by the applicant.

\section{Legal advice}

This legal advice is a representation regarding what must be carried out by the applicant and the defendant in the trial. The officers here only provide accommodation to make it easier for each person who is facing the trial due to ignorance to the procedure for proceedings in the Courts. The Legal Aid Post also cannot act as an advocate in court.

\section{Assistance in making legal documents (legal documents)}

The officer can make the applicant for legal aid services, the necessary legal documents such as lawsuit documents. The applicant first informs the problem in chronological order until a lawsuit is proposed to the Court. If the problem explained by the applicant can be proposed to the Court, the officer can assist in making the lawsuit document. In addition to the lawsuit document, the officer can also assist the applicant in making other legal documents as well as those relating to filing an appeal, cassation, or review.

\section{Provision of information related to the register of Legal Aid Institutions}

The officer also provided information regarding the register of Legal Aid Institutions that can provide free legal aid services. Based on an explanation from the officer, the litigants submitted a request for assistance from a legal aid institution established by the government. The Court's Legal Aid Post does not deserve to run it, so it is less efficient. ${ }^{31}$

In the earlier discussion, it has been explained that the function of the Legal Aid Post in the Religious Courts is still ineffective, due to the fact that the provision of legal aid services is not only making of lawsuit documents related to the case but also providing assistance to the applicant in resolving cases to obtain permanent legal force. The court's Legal Aid Post also has a role not only as a provider of information about the register of legal aid organizations but also as provider that play a direct role in proceedings. It calls into question if the Legal Aid Post agency only acts as a provider of information which suggested that the applicant can take advantage of mentoring services by an advocate for free.

We recommend that the Legal Aid Post can directly provide legal advocacy for free so that the applicant does not have to look for other legal aid institutions that provide free legal aid services. Recipients of the Legal Aid service, according to the interview results, complained that there was no direct legal advocacy. ${ }^{32}$ Providing direct advocacy will make it easier for the parties to hold proceedings and resolve

31 Legal Advice Officer.

32 Siti Hardiati (Legal Service Recipient), "Interview by Muslim Lobubun on June 2," 2021. 
the problems they face. The Legal Aid service is very useful for the people in general. Recipients stated that it was very helpful to have the Legal Aid Post Institute at Biak's Religious Court because the applicant did not know about the legal procedures and they must be passed. ${ }^{33}$

The existence of the Legal Aid Post can provide benefits to the community in resolving legal cases. Moreover, court's Legal Aid officers can provide direct assistance to recipients of Legal Aid services. Based on the data obtained by the researcher, it can be seen that the legal aid services provided by the Legal Consultation and Aid Center (LKBH) of Biak's College of Law for 2020 amounted to 3 services, meanwhile there were 31 cases in which the litigants used the legal aid service.

Services provided by Dr. Muslim Lobubun, S.H., M.H., \& Partners in 2020 totaled 3 services, and litigants who used the legal services of the Legal Aid Post amounted to 31 cases. According to data until July 2021, the Legal Aid Officer of Biak's Religious Court has realized legal aid services as many as 3 services and litigants who utilized the Legal Aid services from January to early June amounted 15 cases.

It is quite clear that the function of the Legal Aid Post is very useful for underprivileged communities who do not know legal procedures and can also realize the principles of simple, fast, and low-cost justice. The court's Legal Aid Post has duties as described in the provisions of Article 28 of the Supreme Court Decree Number 1 of 2014. The mandated task has been carried out properly by the Legal Aid Officer through the provision of responsible and professional services, providing accurate and clear legal and other information, as well as providing comprehensive and proportionate legal consultation or advice.

As legal scholars, the officers first obtain written permission from an advocate at the

\footnotetext{
33 Siti Hardiati (Legal Service Recipient).
}

Court's Legal Aid Service Provider, Dr. Muslim Lobubun, S.H., M.H. \& Partners, in making legal documents. ${ }^{34}$ In addition, there is also a prohibition for the officers of the Legal Aid Post in accordance with the provisions of Article 30 of the Supreme Court Decree Number 1 of 2014. The prohibition calls into question mainly in point $f$ which prohibits Legal Aid Post officers from providing services for the applicant and the defendant in a case draft by the same Court Legal Aid Officer.

What if there are two legal aid services in one case, both of whom are poor people who cannot afford to pay for the services of an advocate so they use court's Legal Aid Service. The results of interviews with officers mentioned that there had been a case in which both parties, required legal aid services by the Court's Legal Aid Post. This is certainly prohibited and the officer can notify the legal basis in accordance with Article 30 letter $f$ and if it is still given it will injure the professional code of ethics for the advocate. ${ }^{35}$

This will cause losses for any parties who need the Legal Aid service. There should be a restriction related to the making of legal documents and also legal advice about the material of the case, if the litigants want information, and consultation on court procedures and, they are allowed to use the Court's Legal Aid service. The Court's Legal Aid Post also has the authority to own and occupy facilities and infrastructure that assists in establishing the provision of legal aid according to the Supreme Court Decree Number 1 of 2014 Article 29.

Biak's Religious Court needs to prepare a room to facilitate the management of the Legal Aid Post. This has been implemented with an existing special table for legal services in the

34 Legal Aid Post Officer, "Interview by Muslim Lobubun on 2 June," 2021.

35 Legal Aid Post Officer. 
courtrooms. The officer stated that the existing facilities and infrastructure include tables and chairs, computer equipment, printers, and also stationery equipment (Office Stationery). ${ }^{36}$ These facilities are certainly very useful to support the implementation of the Legal Aid Post itself.

The MoU agreement between Biak's Religious Court and the Kyadiren's Legal Aid Post Service Organization stipulates that the budget is charged in the form of providing and managing the facilities needed at the Court's Legal Aid Post which includes at least one room, table, and chair. In accordance with the agreement, the word "minimum" can be interpreted as the ability to provide more than just facilities based on provisions of the Supreme Court Decree Number 1 of 2014.

Based on the Circular Letter of the Director-General of the Religious Courts of the Supreme Court decree Number: 0508.a/ DjA/HK.00/III/2014 March 26, 2014 regarding technical guidelines for the realization of the Regulation of the Supreme Court decree Number 1 of 2014 Article 27, Court stipulated that $^{37}$ :

1. The provision of legal aid services at is listed based on the attached form.

2. The registration as referred to paragraph (1) can be carried out through computer media which is printed at the end of month and initialed by an officer and forwarded to the Head of the Religious Court through the Secretary or Clerk.

It is quite clear that the officers should make reports through the use of computer media.

36 Legal Aid Post Officer.

37 Direktur Jenderal Badan Peradilan Agama, "Surat Edaran Direktur Jenderal Badan Peradilan Agama Nomor 0508.a/DjA/HK/00/III/2014 Tentang Petunjuk Teknis Pelaksanaan Peraturan Mahkamah Agung Republik Indonesia Nomor 1 Tahun 2014 Tentang Pedoman Layanan Hukum Bagi Masyarakat Miskin Di Pengadilan.” (2014).
Computers can be considered as the main tool when making reports. Crucial facilities and infrastructure in carrying out the service are stationary equipment. The equipment is used by the officers to work in every service to the applicant. The equipment includes paper as used to complete service requests, to make lawsuits and other legal documents, to make reports, pens to write down the number of services, folders to file archives, and other items. Biak's Religious Court should include the equipment for Legal Aid Posts in its budgeting. In addition, there is also a budget for the procurement of the Equipment.

Another right that can be owned by the Legal Aid Post is to obtain an honorarium according to the institutional MoU agreement. It was previously explained that, the 2020 budgeted funds for Court's Legal Aid services amounted to Rp. 76,000,000 (seventy six million rupiah). It is still the same as 2021 budget.

Based on the MoU between Biak's Religious Court and Kyadiren's Legal Aid Service Provider on the Provision of 2021 Legal Aid Services, it was determined that:

1. Provisions on the amount of service fee for officers are regulated according to the court's 2021 budget execution document.

2. The amount of fee is determined based on the length of time the Court's Legal Aid services provided by the institution.

In 2021, the budget for the cooperation agreement is charged from the court's 2021 budget execution document which is amounted to Rp. 76.000.000,00- (seventy six million rupiah). ${ }^{38}$ Furthermore, in the Letter of Agreement or Work Contract on March 2, 2021, it is stipulated that the payment of the legal aid service will be calculated for each Court's Legal Aid officer and paid Rp.

38 Biak's Religious Court, “Legal Aid Post Cooperation Agreement." 
250.000,00- (two hundred and fifty thousand rupiahs) per hour of service. ${ }^{39}$ This is also to see the number of assistance services and picket officers according to the provision of Legal Aid Post services, Article 24 paragraph (2) of the Supreme Court decree Number 1 of 2014 that the head of the Court will determine the schedule and number of officers in Court.

The control over the assistance services is carried out by the Head of the Court. Daily supervision is carried out by the Clerk and submits it to the Chairperson. This is based on the provisions of 36 Supreme Court regulations. The rights and obligations in the cooperation agreement have also stipulated:

1. Determine the composition of the court's Legal Aid Post officers and the procedure for structuring the rotation of officers and forward the application to the Chief Justice.

2. Determine the schedule of hours and working days of service.

The arrangement of the picket schedule and the officer list have been determined by the Institution that collaborates with Biak's Religious Court, as shown in 2020 data. The picket officers at the Legal Consultation and Aid Institute of Biak's College of Law consist of: ${ }^{40}$

1. Hamza Toatubun, S.H., M.H.

2. Djamaluddin, S.H., M.H.

3. Rika Annisa.

4. Karizma Dwi Yanti.

The Legal Aid officers at the Advocate's Office, Dr. Muslim Lobubun, S.H., M.H. \& Partners consists of: ${ }^{41}$

1. Turang Tengko, S.H., M.H.

2. Lajahadin, S.H.

\footnotetext{
39 Biak's Religious Court.

40 STIH Biak-Papua, "The Pick-up Schedule for Legal Consultation and Aid Institute Officers," 2020.

41 Muslim Lobubun SH MH \& Partners, "The Pick-up Schedule For Advocate Office Officers," 2020.
}

Based on the data of the picket officers, it can be seen that the institutions that collaborate with the Court rarely involve students in the work of the court's Legal Aid officer. This proves that the available legal aid services have been implemented ideally. If the student acts as the picket officer, it will take a longer time. Students certainly cannot provide direct consultation regarding the subject matter, which must first seek advice from advocates or go to advocates so that legal procedural errors do not occur in providing solutions for applicants in resolving their cases. Students only carry out their duties as a room guard in court.

Regarding the supervisory role, every legal service officer is made up of monthly attendance arrangements. Apart from a supervisory role, it is aimed to calculate the totally expected legal services that must be paid for the officers. Based on the provisions of the Circular of the Director-General of the Religious Courts Agency Article 24 Number 0508.a/DA/HK/ III/2014 on Guidelines for the Implementation of the Supreme Court decree Number 1 of 2014, it is clearly stated that:

1. The religious court and legal aid service provider institutions are responsible for conducting periodic evaluations at least once every 3 (three) months regarding the realization of cooperation agreements;

2. The religious court and legal aid service provider institutions hold coordination meetings at least 2 (two) times a year to review existing problems and progress related to the cooperation.

3. In providing maximum and integrated legal aid post services, the religious court and can coordinate with stakeholders at the regional or provincial level.

The Legal Aid Post officer is also responsible for filling out the special registration given by Biak's Religious Court regarding the implementation of the Legal Aid Post and 
reporting it to the Chairperson. The officers are also responsible for compiling reports every month to then submit the report to the Chief Justice as a responsibility in providing legal aid services. According to the Deputy Clerk of Biak's Religious Court, the officers are required to prepare reports, and if they do not fulfill their duties, the Court will consider the officer not to carry out legal service duties, therefore payment of legal services for the institution cannot be delivered. ${ }^{42}$

The Court takes into consideration whether the Legal Institution is deemed to meet the feasibility of re-cooperating with the Court. In 2020, it can be seen that the Legal Aid Institute in collaboration with Biak's Religious Court has carried out its duties, namely compiling reports on the Legal Aid services. Therefore, the Courts then make payments for these legal services because it is considered responsible for their duties.

\section{CONCLUSION}

The legal aid post at Biak's religious court is crucial to encourage judges and clerks, especially in formulating lawsuits or applications. Due to the establishment of the legal aid office at the court, the duties of the clerks become the legal aid office obligation. Based on services provided by the legal aid post, it fits the provisions of the Supreme Court Regulation. In implementing its duties, it has provided legal services, provided information and legal consultations, formulated lawsuits and requests to disadvantaged people. However, the post at Biak's religious court faces some challenges in carrying out their duties, including uncooperative, dishonest, and convoluted in deciphering information from applicants, lack of knowledge on the inheritance law from the officers, and no direct assistance for justice seekers in the proceedings.

42 Legal Aid Post Officer, "Interview by Iryana Anwar on 2 June," 2021.

\section{REFERENCES}

Ahyar. "Optimalisasi Pelayanan Bantuan Hukum Bagi Masyarakat Miskin.” Jurnal Penelitian Hukum De Jure 20, no. 3 (2020): 409-34. https://doi.org/10.30641/ dejure.2020.V20.409-434.

Angga, and Ridwan Arifin. "Penerapan Bantuan Hukum Bagi Masyarakat Kurang Mampu Di Indonesia." Diversi Jurnal Hukum 4, no. 2 (2018): 218-36.

Biak's Religious Court. "2020 Annual Report," 2020.

- "January-May Case Report," 2020.

. "Legal Aid Post Cooperation Agreement," 2020.

. "Report on the Implementation of Legal Aid Post Services,” 2020.

"Report on the Implementation of the Realization of Legal Aid Service in July," 2020.

Deputy Clerks \& Legal Advice Officer. "Interview by Muslim Lobubun, Biak Religious Court Class IIB Biak On 12 May," 2021.

Direktur Jenderal Badan Peradilan Agama. Surat Edaran Direktur Jenderal Badan Peradilan Agama Nomor 0508.a/DjA/ HK/00/III/2014 tentang Petunjuk Teknis Pelaksanaan Peraturan Mahkamah Agung Republik Indonesia Nomor 1 Tahun 2014 tentang Pedoman Layanan Hukum Bagi Masyarakat Miskin di Pengadilan. (2014).

Dr Muslim Lobubun SH MH \& Partners. "The Pick-up Schedule For Advocate Office Officers," 2020.

Eleanora, Fransiska Novita. "Bantuan Hukum Dan Perlindungan Hak Asasi Manusia Bagi Tersangka." Lex Jurnalica 9, no. 3 (2012): 142-50.

Fauzan. "Penerapan Pemberian Bantuan Hukum Bagi Masyarakat Miskin Melalui Posbakum Di Pengadilan Agama Kota 
Bengkulu." MIZANI:Wacana Hukum, Ekonomi Dan Keagamaan 4, no. 2 (2017): 125-34.

Hariyanto, Erie, Mohamad Efendi, and Sulistiyawati. "Dilema Hakim Pengadilan Agama Dalam Menyelesaikan Perkara Hukum Keluarga Melalui Mediasi." Volksgeist: Jurnal Ilmu Hukum \& Konstitusi 4, no. 1 (2021): 115-24. https:// doi.org/10.24090/volksgeist.v3i1.4333.

Hariyanto, Hariyanto. "Peran LBH Kampus Di PTKIN Dalam Bantuan Hukum Terhadap Masyarakat Miskin." Al-'Adl 10, no. 1 (2017): 68-83. https://doi.org/10.31332/ ALADL.V10I1.689.

Irianto, Sulistyowati. "Metode Penelitian Kualitatif Dalam Metodologi Penelitian Ilmu Hukum." Jurnal Hukum \& Pembangunan 32, no. 2 (2020): 15572. https://doi.org/10.21143/jhp.vol32. no2.1339.

Kamil Ardiansyah, Mohammad. "Hukum Acara Perdata Di Lingkungan Peradilan Agama." Jurnal Ilmiah Kebijakan Hukum 14, no. 2 (2020): 361-84. https://doi. org/10.30641/kebijakan.2020.V14.361384.

Legal Advice Officer. "Interview By Lobubun Muslim, Biak’s Religious On 27 May," 2021.

_. "Interview By Lobubun Muslim, Biak Religious Court Class IIB Biak On 12 May," 2021.

Legal Aid Post Officer. "Interview by Iryana Anwar on 2 June," 2021.

_. "Interview by Muslim Lobubun on 2 June," 2021.

Mahkamah Agung. Surat Edaran Mahkamah Agung Nomor 10 Tahun 2010 tentang Pedoman Pemberian Bantuan. (2010).

Perma. Pasal 25 Peraturan Mahkamah Agung Republik Indonesia Nomor 1 Tahun 2014 tentang Pedoman Pemberian Bantuan Hukum Bagi Masyarakat yang Tidak Mampu di Pengadilan. (2014).

Putri Pertiwi, Nyimas Lidya, and Firmansyah. "Peran Posbakum Di Pengadilan Agama Metro Masa New Normal." Jurnal AsSalam 10, no. 1 (2021): 31-46. https:// doi.org/10.51226/assalam.v10i1.213.

Raharjo, Agus, Angkasa, and Rahadi Wasi Bintoro. "Akses Keadilan Bagi Rakyat Miskin (Dilema Dalam Pemberian Bantuan Hukum Oleh Advokat)." MIMBAR HUKUM 27, no. 3 (2015): 432-44.

Ramdan, Ajie. "Bantuan Hukum Sebagai Kewajiban Negara Untuk Memenuhi Hak Konstitusional Fakir Miskin." Jurnal Konstitusi 11, no. 2 (2014): 233-55.

Rosita. "Eksistensi Pos Bantuan Hukum Dalam Memberikan Bantuan Hukum Di Pengadilan Agama Kelas I B Watampone." Jurnal Ekspose 16, no. 1 (2017): 250-60.

Salamor, Yonna Beatrix. "Pemberian Bantuan Hukum Kepada Masyarakat Miskin Di Kota Ambon." Jurnal Muara: Ilmu Sosial, Humaniora \& Seni 2, no. 1 (2018): $277-$ 83. https://doi.org/10.24912/jmishumsen. v2i1.1681.

Setiawan, Gregorius Yolan, Anak Agung Sagung Laksmi Dewi, and I Made Minggu Widyantara. "Efektivitas Bantuan Hukum Advokat Di Pos Bantuan Hukum (Posbakum) Pengadilan Negeri Denpasar Kelas I A." Jurnal Konstruksi Hukum 2, no. 2 (2021): 373-78. https:// doi.org/10.22225/jkh.2.2.3258.373-378.

Siti Hardiati (Legal Service Recipient). "Interview by Muslim Lobubun on June $2, " 2021$.

STIH Biak-Papua. "The Pick-up Schedule for Legal Consultation and Aid Institute Officers," 2020. 
Supriyadi. Etika Dan Tanggung Jawab Profesi Hukum Di Indonesia. Jakarta: Sinar Grafika, 2008.

Syahputra Nasution, Isnandar. "Urgensi Peran Pengadilan Dalam Memberikan Pelayanan Bantuan Hukum Terhadap
Orang Miskin Sesuai Undang-Undang Nomor 16 Tahun 2011 Tentang Bantuan Hukum." Jurnal Hukum Dan Peradilan 4, no. 1 (2015): 171-88.

Undang-undang Nomor 16 Tahun 2011 tentang Bantuan Hukum (2011). 